\title{
The role of hypermethylation of the $h M L H 1$ promoter region in HNPCC versus MSI+ sporadic colorectal cancers
}

\author{
J M D Wheeler, A Loukola, L A Aaltonen, N J McC Mortensen, W F Bodmer
}

\begin{abstract}
Introduction-Hypermethylation of the promoter region of the $h M L H 1$ gene is associated with absent expression of MLH1 protein in sporadic colorectal cancers with microsatellite instability (MSI+), and it has been proposed that methylation may be a mechanism of inactivation in Knudson's hypothesis. The incidence of hypermethylation of the hMLH1 promoter in hereditary nonpolyposis colorectal cancer (HNPCC) versus MSI+ sporadic colorectal cancer was investigated and compared.
\end{abstract}

Methods-DNA was available from 10 HNPCC colorectal cancers (median age 58 years, range 39-67) with germline mutations in $h M L H 1$ and $10 \mathrm{MSI}+$ sporadic colorectal cancers (mean age 79 years, range 41-85). MSI was determined by amplification of BAT 26 and TGF- $\beta$ RII. The methylation status of the $h M L H 1$ promoter was studied by the polymerase chain reaction (PCR) based $\mathrm{HpaII}$ restriction enzyme assay technique. Evidence of allelic loss at $h M L H 1$ was searched for in the HNPCC colorectal cancers.

Results-All cases were confirmed to be MSI+. The promoter region of $h M L H 1$ was hypermethylated in seven of $10 \mathrm{MSI}+$ sporadic cancers versus 0 of 10 HNPCC cancers $(p<0.002)$. Evidence of loss of heterozygosity at $h M L H 1$ was observed in eight of the $10 \mathrm{HNPCC}$ colorectal cancers. Conclusion-While mutations and allelic loss are responsible for the MSI+ phenotype in HNPCC cancers, the majority of MSI+ sporadic cancers are hypermethylated in the promoter region of $h M L H 1$. These data further support our argument that tumours from HNPCC patients, which almost always acquire a raised mutation rate, mostly follow a different pathway from MSI+ sporadic tumours. (f Med Genet 2000;37:588-592)

Keywords: $h M L H 1$ promoter region; HNPCC; hypermethylation; colorectal cancer

Hereditary non-polyposis colorectal cancer (HNPCC) is caused by germline mutations in the DNA mismatch repair (MMR) genes. ${ }^{1}$ To date, inactivating mutations have been described in five mismatch repair genes: $h M S H 2$, $h M L H 1$, hPMS1, hPMS2, and GTBP (hMSH6). ${ }^{2-9}$ These cancers, from affected HNPCC kindreds, exhibit genomic instability which can be detected as changes in the length of microsatellite sequences. ${ }^{10}$ Almost all colorectal cancers (CRC) removed from patients with HNPCC show microsatellite instability (MSI+) or are replication error positive (RER +$),{ }^{10}$ and this contrasts with approximately $15-20 \%$ of sporadic CRC from patients with no obvious family history. ${ }^{11}$ Approximately $70 \%$ of HNPCC patients with MSI+ tumours are found to have germline mutations in one of the mismatch repair genes. ${ }^{12}$ The majority of these mutations (95\%) have been described in $h M L H 1$ and $h M S H 2,{ }^{13}$ with mutations in other mismatch repair genes being rare. ${ }^{13}$ In contrast, somatic mutations in the mismatch repair genes are rarely described in MSI+ sporadic CRC. ${ }^{14}{ }^{15}$ Epigenetic mechanisms which inactivate genes, such as promoter region hypermethylation resulting in transcriptional loss, have been described in a number of tumour suppressor genes, ${ }^{16}$ and recently it has been shown that hypermethylation of the promoter region of the $h M L H 1$ gene may cause a lack of expression of its protein and therefore account for microsatellite instability in MSI+ sporadic CRC. ${ }^{12}{ }^{17-20}$

With the recognition that methylation of the promoter region may inactivate tumour suppressor genes, Jones and Laird ${ }^{21}$ have proposed that Knudson's hypothesis, for the inactivation of tumour suppressor genes, should be expanded to include epigenetic mechanisms of gene inactivation, such as hypermethylation of the promoter region. We have therefore studied a panel of HNPCC CRC, and compared this to a panel of MSI+ sporadic CRC, to determine whether hypermethylation of the $h M L H 1$ promoter region is a common "second hit" mechanism of inactivation in both of these two cancers.

\section{Methods}

MATERIALS

Tumour DNA was available from 10 HNPCC family members with CRC (median age 58 years, range 39-67) and from $10 \mathrm{MSI}+$ sporadic CRC (mean age 79 years, range 41-85), at the University of Helsinki, Finland. The MSI status of all tumours was determined by amplification of BAT2 6 and TGF- $\beta$ RII mononucleotide markers as previously described. ${ }^{22}$ The HNPCC family members all carried germline mutations in $h M L H 1$. This included six patients with the Finnish founder mutation 1 (a $3.5 \mathrm{~kb}$ genomic deletion of $h M L H 1$ comprising exon 16) detected by PCR specific for the normal and mutated allele which are then size fractionated by agarose gel electrophoresis. ${ }^{23}$ Three patients had the Finnish founder mutation 2 (a single bp 
Table 1 HNPCC versus MSI+ sporadic CRC

\begin{tabular}{|c|c|c|c|}
\hline & HNPCC & MSI+ sporadic & p value \\
\hline Male:female & $8: 2$ & $5: 5$ & \\
\hline Median age & 58 & 79 & $0.01<\mathrm{p}<0.05^{\star}$ \\
\hline \multicolumn{4}{|l|}{ Tumour site } \\
\hline Right & 4 & 7 & \\
\hline Left & 2 & 0 & \\
\hline Rectum & 4 & 3 & \\
\hline \multicolumn{4}{|l|}{ Dukes' stage } \\
\hline A & 2 & 1 & \\
\hline $\mathrm{B}$ & 6 & 4 & \\
\hline $\mathrm{C}$ & 2 & 5 & \\
\hline Germline mutation in $h M L H 1$ & 10 & 0 & \\
\hline Hypermethylated $h M L H 1$ & 0 & 7 & $\mathrm{p}<0.002 \dagger$ \\
\hline Loss of heterozygosity & 8 & ND & \\
\hline
\end{tabular}

substitution, cagGTG $\rightarrow$ caaGTG, at the exon 6 acceptor splice site in $h M L H 1$ ), which was detected by allele specific oligonucleotide hybridisation, ${ }^{23}$ and one patient had a nonsense mutation in exon 4 of $h M L H 1$ detected by direct sequencing (codon 126, TAC $\rightarrow$ TAG, Tyr $\rightarrow$ Stop). No mutations were detected in the germline DNA from patients with MSI+ sporadic cancers, which were directly sequenced throughout the coding region (including the intron/exon borders) and the promoter region of $h M L H 1$ and $h M S H 2$.

\section{METHYLATION STATUS}

Hypermethylation of the $h M L H 1$ promoter region was ascertained by a PCR based HpaII restriction enzyme assay. ${ }^{12}$ A total of $250 \mathrm{ng}$ of genomic DNA from each tumour was digested separately by $H p a \mathrm{II}$ and $M s p \mathrm{I}$ in $20 \mu \mathrm{l}$ volumes of restriction enzyme buffer (New England Biolabs). DNA from each sample was also added to $20 \mu \mathrm{l}$ of restriction enzyme buffer without enzyme, as a control. A total of $25 \mathrm{ng}$ of DNA from each digest was analysed by PCR in $50 \mu \mathrm{l}$ reactions using conditions and primers, for the promoter region of $h M L H 1$, as previously described. ${ }^{12}$ PCR products were observed by agarose gel electrophoresis. Fisher's exact value was calculated for the incidence of hypermethylation of the $h M L H 1$ promoter region in HNPCC cancers versus MSI+ sporadic cancers.

LOSS OF HETEROZYGOSITY (LOH) ANALYSIS

LOH studies were performed on all 10 HNPCC cancers. Owing to slippage at DNA repeat sequences in MSI+ cancers and subsequent difficulty in the interpretation of results, we did not use CA repeat markers to study LOH. For mutation 1, radiolabelled PCR using previously described primers, specific for the normal and mutated allele, ${ }^{23}$ was performed on tumour and normal DNA and the alleles were size fractionated by polyacrylamide gel electrophoresis. The intensities of each band were analysed, using the BAS-MP2040 Fujifilm Imaging Plate for Bio Imaging Analyzer (Fuji Photo Film Co Ltd, Japan) in six positions (two positions centrally and four positions from the perimeter) and a mean value calculated. The ratio of the normal (T1) and mutant (T2) bands from the tumour ( $\mathrm{T} 1: \mathrm{T} 2$, where $\mathrm{T} 1$ is the smaller value) was compared to the

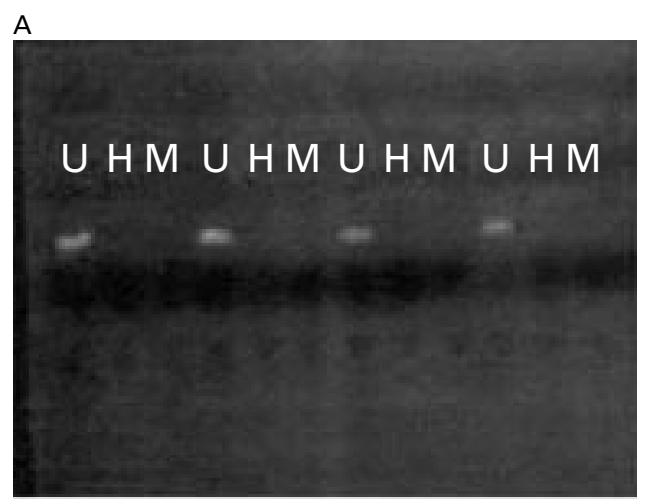

B

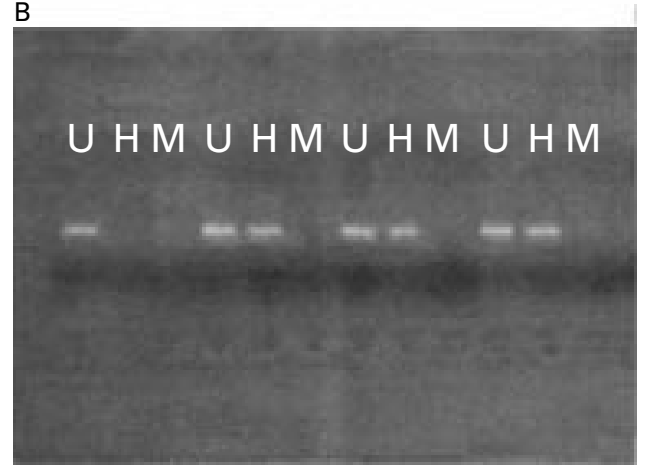

Figure 1 Representative results from PCR based HpaII restriction enzyme assay. All 10 HNPPC cancers (A) were unmethylated in the hMLH1 promoter region, while seven of $10 \mathrm{MSI}+$ sporadic cancers (B) were methylated ( $p<0.002)$. A PCR product is seen following incubation with HpaII in a methylated cancer, as the methylated restriction site (CCGG) is resistant to digestion by the enzyme (U, undigested; $H$, incubated with HpaII; $M$, incubated with MspI).

germline ratio $(\mathrm{N} 1: \mathrm{N} 2$, where $\mathrm{N} 1$ is the smaller value) and an allele ratio obtained (T1:T2/ $\mathrm{N} 1: \mathrm{N} 2$ ). LOH was declared when the allele ratio was less than 0.6 or greater than 1.67 , as previously defined. ${ }^{24}$

For mutation 2 and the exon 4 nonsense mutation, quantification of allelic loss was more difficult, but evidence of LOH was declared in the presence of a higher wild type: mutant allele ratio in normal DNA when compared to tumour DNA following direct sequencing.

\section{Results}

The clinicopathological features of the HNPCC cancers and MSI+ sporadic cancers are shown in table 1. The HNPCC cancers, as expected, had a younger median age, 58 years versus 79 years, at presentation (Mann Whitney $U$ test, $0.01<p<0.05)$. All cancers were confirmed as MSI+.

The promoter region of $h M L H 1$ was hypermethylated in seven of $10 \mathrm{MSI}+$ sporadic cases versus 0 of $10 \mathrm{HNPCC}$ cases (Fisher' exact test, $\mathrm{p}<0.002$ ) (fig 1 ).

There was at least some evidence of loss of heterozygosity at $h M L H 1$ in eight of the 10 HNPCC colorectal cancers (table 2). Radiolabelled PCR showed evidence of $\mathrm{LOH}$ in four of five cancers from patients with the Finnish founder mutation 1 (the remaining cancer was 
Table 2 Mean allele ratio for Finnish founder mutation 1 using radiolabelled PCR specific for the normal and mutated allele, which are then size fractionated by agarose gel electrophoresis and analysed for intensities of mutant and wild type alleles

\begin{tabular}{lll}
\hline Sample & Mean allele ratio & Allele loss \\
\hline 1 & 1.19 & No \\
2 & 0.47 & Yes \\
3 & 0.48 & Yes \\
4 & 0.49 & Yes \\
5 & ND & ND \\
6 & 0.32 & Yes \\
\hline
\end{tabular}

$\mathrm{ND}$, not determined.

uninformative). The other four patients showed evidence of $\mathrm{LOH}$ on direct sequencing (fig 2).

\section{Discussion}

None of the 10 HNPCC cancers were hypermethylated in the $h M L H 1$ promoter region, and these results suggest that methylation is not a common "second hit" mechanism in the inactivation of mismatch repair genes in HNPCC cancers. Although Jones and Laird ${ }^{21}$ have recently pointed out that Knudson's two hit hypothesis should extend to include epigenetic mechanisms of gene inactivation, such as methylation, this would only appear to be true of MSI+ sporadic cancers in the case of $h M L H 1$. Hypermethylation of the $h M L H 1$ promoter is responsible for the MSI+ phenotype in as many as $80 \%$ of MSI+ sporadic colorectal cancers. ${ }^{17}$ Hypermethylation of the promoter region has not been reported in $h M S H 2$, although this is not surprising as Thibodeau $e t ~ a l^{14}$ have reported that $h M L H 1$ is the altered protein in more than $90 \%$ of MSI+ sporadic CRC. As we had not detected methylation in the HNPCC cancers, we sought evidence of allelic loss as the "second hit".

As there are technical difficulties with studying allelic loss in MSI+ cancers, we used the germline mutations as specific $\mathrm{LOH}$ markers, and were able to detect at least some evidence of LOH at hMLH1 in eight of the 10 HNPCC cancers, and the finding of frequent allelic loss at this locus is in keeping with others. ${ }^{25}{ }^{26}$ In contrast, it has been shown that hypermethylation of the $h M L H 1$ promoter region is a biallelic event in MSI+ sporadic CRC and is not accompanied by LOH. ${ }^{18} 20$

Mutations which are relatively common, such as the Finnish founder mutations, are likely to have arisen many tens or hundreds of generations ago. The pedigrees with founder mutations in this series have been extended two to four generations back (and horizontally) and are known to be unrelated. Although it is conceivable that the selective advantage associated with the two most frequent HNPCC mutations in Finland (nine of 10 cases in this series) leads to a particular second event (LOH and not methylation), this would seem unlikely. Common lineage would not be expected five or 10 generations ago, let alone the time that has passed since these mutations arose.

The underlying event which leads to methylation may be a change in some aspect of chromatin structure possibly connected with histone acetylation, ${ }^{27}$ which enables recently
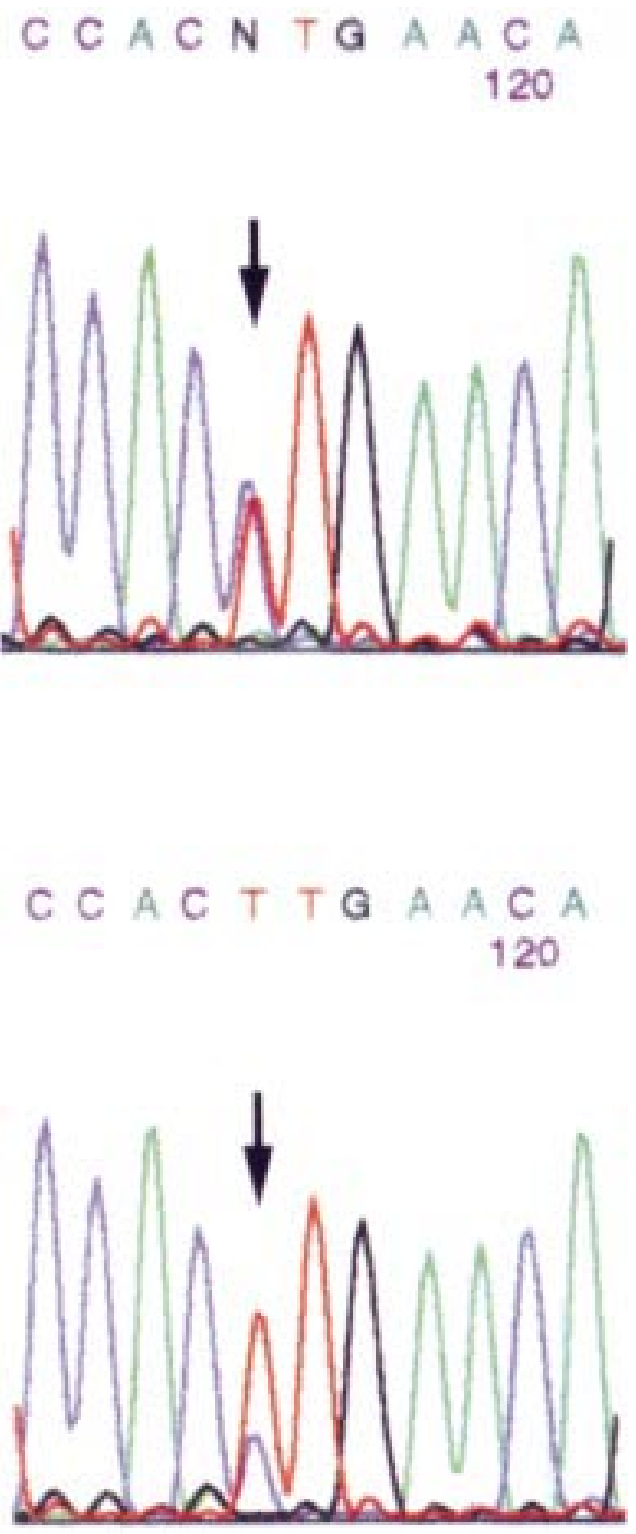

Figure 2 For Finnish founder mutation 2, loss of heterozygosity (LOH) was declared in the presence of a higher wild type:mutant allele ratio in normal DNA when compared to tumour DNA following direct sequencing. Reverse sequencing of $h M L H 1$, exon 6, from a patient with the founder mutation 2 (a single bp substitution, cagGTG $\rightarrow$ caaGTG, at the exon 6 acceptor splice site in hMLH1) is shown. A higher wild type:mutant allele ratio (arrows) is seen in the normal DNA (above) when compared to the tumour DNA (below).

described methyl transferases ${ }^{28}$ to have access to the DNA. Previous work has shown that methylation may accompany missense mutations in $h M L H 1$ in MSI+ sporadic CRC, ${ }^{20}$ but it is not clear which event occurs first. Presumably, a missense change precedes methylation or one allele is methylated before the other, otherwise there would be no basis for selection for a missense mutation.

Others have shown that MSI+ sporadic CRC may be a subgroup of tumours which have increased promoter region hypermethylation in a number of genes, including p16 and IGFII. ${ }^{29}$ Thus, the inactivation of $h M L H 1$ by promoter region hypermethylation may, in 
turn, enhance the rate of further genetic events in MSI+ sporadic cancers. ${ }^{21}$

The majority of MSI+ sporadic cancers are hypermethylated in the promoter region of $h M L H 1$, while mutations and allelic loss are responsible for the MSI+ phenotype in HNPCC cancers. These data further support our argument that tumours from HNPCC patients, which almost always acquire a raised mutation rate, mostly follow a different pathway from MSI+ sporadic tumours. ${ }^{30}{ }^{31}$ In the latter, we believe that a single mutation or methylated allele initially will be selected for, and that the subsequent event leading to the MSI+ phenotype does not occur particularly early in the adenoma to carcinoma sequence. At this late stage, the mutation rate is less limiting because of increased population size and possibly other constraints on tumour growth. This prediction is supported by experimental evidence. ${ }^{32}$

Germline mutations in HNPCC patients occur throughout $h M L H 1$ and $h M S H 2$, although nine of 10 mutations in this series are $h M L H 1$ founding mutations originating in Finland. ${ }^{23} 33$ In contrast, $h M L H 1$ is inactivated, whether by mutation or methylation, in the majority of MSI+ sporadic CRC. ${ }^{20}{ }^{34}$ This situation is analogous to APC, with the majority of somatic mutations occurring in the mutation cluster region. It is likely that the selective advantage needed to promote tumour outgrowth is much less for germline mutations, which occur in all cells, than for somatic mutations.

Selection for inactivation of a mismatch repair gene may be for resistance to apoptosis, as is the case for $p 53$ mutations, ${ }^{35}$ and not an increased mutator phenotype. Recently, it has been shown that apoptosis can be induced by the overexpression of $h M S H 2$ or $h M L H 1 .^{36}$ This produces the possibility that HNPCC and MSI+ sporadic cancers lose the ability to undergo efficient apoptosis.

In conclusion, while hypermethylation of the $h M L H 1$ promoter is responsible for the MSI+ phenotype in the majority of MSI+ sporadic CRC, it is not a common "second hit" mechanism of inactivation of mismatch repair genes in HNPCC CRC.

1 Peltomaki P. Microsatellite instability and hereditary non-polyposis colon cancer. F Pathol 1995;176:329-30.

2 Akiyama Y, Sato H, Yamada T, Nagasaki H, Tsuchiya A, Abe R, Yuasa Y. Germ-line mutation of the hMSH6/GTBP Abe R, Yuasa Y. Germ-line mutation of the hMSH6/GTBP
gene in an atypical hereditary nonpolyposis colorectal cangene in an atypical hereditary nonpolyposis

3 Miyaki M, Konishi M, Tanaka K, Kikuchi-Yanoshita R, Muraoka M, Yasuno M, Igari T, Koike M, Chiba M, Mor T. Germline mutation of MSH6 as the cause of hereditary nonpolyposis colorectal cancer. Nat Genet 1997; 17:271-2.

4 Fishel R, Lescoe MK, Rao MR, Copeland NG, Jenkins NA, Garber J, Kane M, Kolodner R. The human mutator gene homolog $\mathrm{MSH} 2$ and its association with hereditary nonpolyposis colon cancer. Cell 1993;75:1027-38.

5 Leach FS, Nicolaides NC, Papadopoulos N, Liu B, Jen J, Parsons R, Peltomaki P, Sistonen P, Aaltonen LA, Nystrom-Lahti M. Mutations of a mutS homolog in hereditary nonpolyposis colorectal cancer. Cell 1993;75: 1215-25.

6 Bronner CE, Baker SM, Morrison PT, Warren G, Smith LG, Lescoe MK, Kane M, Earabino C, Lipford J, Lindblom A. Mutation in the DNA mismatch repair gene homologue hMLH1 is associated with hereditary nonhomologue hMLH1 is associated with heredit
polyposis colon cancer. Nature 1994;368:258-61.

polyposis colon cancer. Nature 1994;368:258-61.
7 Papadopoulos N, Nicolaides NC, Wei YF, Ruben SM, Carter KC, Rosen CA, Haseltine WA, Fleischmann RD, Carter KC, Rosen CA, Haseltine WA, Fleischmann RD,
Fraser CM, Adams MD. Mutation of a mutL homolog in hereditary colon cancer. Science 1994;263:1625-9.
8 Nicolaides NC, Papadopoulos N, Liu B, Wei YF, Carter KC, Ruben SM, Rosen CA, Haseltine WA, Fleischmann RD, Fraser CM. Mutations of two PMS homologues in hereditary nonpolyposis colon cancer. Nature 1994;371:7580

9 Papadopoulos N, Nicolaides NC, Liu B, Parsons R, Lengauer C, Palombo F, D'Arrigo A, Markowitz S, Willson ble cells. Science 1995;268:1915-17.

10 Aaltonen LA, Peltomaki P, Leach FS, Sistonen P, Pylkkanen L, Mecklin JP, Jarvinen H, Powell SM, Jen J, Hamilton SR. Clues to the pathogenesis of familial colorectal cancer. Science 1993;260:812-16.

11 Thibodeau SN, Bren G, Schaid D. Microsatellite instability in cancer of the proximal colon. Science 1993;260:816-19.

12 Kane MF, Loda M, Gaida GM, Lipman J, Mishra R, Goldman H, Jessup JM, Kolodner R. Methylation of the hMLH1 promoter correlates with lack of expression of hMLH1 in sporadic colon tumors and mismatch repairdefe 11 .

13 Papadopoulos N, Lindblom A. Molecular basis of HNPCC: mutations of MMR genes. Hum Mutat 1997;10:89-99.

14 Thibodeau SN, French AJ, Roche PC, Cunningham JM, Tester DJ, Lindor NM, Moslein G, Baker SM, Liskay RM, Burgart LJ, Honchel R, Halling KC. Altered expression of hMSH2 and hMLH1 in tumors with microsatellite instability and genetic alterations in mismatch repair genes. Cancer Res 1996;56:4836-40.

15 Borresen AL, Lothe RA, Meling GI, Lystad S, Morrison P, Lipford J, Kane MF, Rognum TO, Kolodner RD. Somatic mutations in the hMSH2 gene in microsatellite unstable colorectal carcinomas. Hum Mol Genet 1995;4:2065-72.

16 Herman JG, Graff JR, Myohanen S, Nelkin BD, Baylin SB. Methylation-specific PCR: a novel PCR assay for methylation status of $\mathrm{CpG}$ islands. Proc Natl Acad Sci USA 1996;93:9821-6.

17 Herman JG, Umar A, Polyak K, Graff JR, Ahuja N, Issa JP, Markowitz S, Willson JK, Hamilton SR, Kinzler KW, Kane MF, Kolodner RD, Vogelstein B, Kunkel TA, Baylin SB. Incidence and functional consequences of hMLH1 proIncidence and functional consequences of hMLH1 pro-
moter hypermethylation in colorectal carcinoma. Proc Natl Acad Sci USA 1998;95:6870-5.

18 Veigl, ML, Kasturi L, Olechnowicz J, Ma AH, Lutterbaugh D, Periyasamy S, Li GM, Drummond J, Modrich PL, Sedwick WD, Markowitz SD. Biallelic inactivation of hMLH1 by epigenetic gene silencing, a novel mechanism causing human MSI cancers. Proc Natl Acad Sci USA 1998;95:8698-702.

19 Cunningham JM, Christensen ER, Tester DJ, Kim CY, Roche PC, Burgart LJ, Thibodeau SN. Hypermethylation of the hMLH1 promoter in colon cancer with microsatellite instability. Cancer Res 1998; 58:3455-60.

20 Wheeler JMD, Beck NE, Kim HC, Tomlinson IPM, Mortensen NJM, Bodmer WF. Mechanisms of inactivation of mismatch repair genes in human colorectal cancer cell lines: the predominant role of hMLH1. Proc Natl Acad Sci lines: the predominant role

21 Jones, PA, Laird PW. Cancer epigenetics comes of age. Nat Genet 1999;21:163-7.

22 Loukola A, Salovaara R, Kristo P, Moisio AL, Kaariainen H, Ahtola H, Eskelinen M, Harkonen N, Julkunen R, Kangas E, Ojala S, Tulikoura J, Valkamo E, Jarvinen H, Mecklin JP, de la Chapelle A, Aaltonen LA. Microsatellite instability in adenomas as a marker for hereditary nonpolyposis colorectal cancer. Am $\mathcal{F}$ Pathol (in press)

23 Nystrom-Lahti M, Kristo P, Nicolaides NC, Chang SY, Aaltonen LA, Moisio AL, Jarvinen HJ, Mecklin JP, Kinzler KW, Vogelstein B. Founding mutations and Alu-mediated recombination in hereditary colon cancer. Nat Med recombination

24 Cawkwell L, Bell SM, Lewis FA, Dixon MF, Taylor GR, Quirke P. Rapid detection of allele loss in colorectal tumours using microsatellites and fluorescent DNA technology. Br f Cancer 1993;67:1262-7.

25 Hemminki A, Peltomaki P, Mecklin JP, Jarvinen H, Salovaara R, Nystrom-Lahti M, de la Chapelle A, Aaltonen LA. Loss of the wild type MLH1 gene is a feature of 8:405-10.
.

6 Tomlinson, IP, Ilyas M, Bodmer WF. Allele loss occurs frequently at hMLH1, but rarely at hMSH2, in sporadic colorectal cancers with microsatellite instability. Br $7 \mathrm{Can}$ cer 1996;74:1514-17.

27 Cameron EE, Bachman KE, Myohanen S, Herman J, Baylin S. Synergy of demethylation and histone deacetylase inhibition in the re-expression of genes silenced in cancer. Nat Genet 1999;21:103-7.

28 Okano M, Xie S, Li E. Cloning and characterization of a family of novel mammalian DNA (cytosine-5) methyltransferases. Nat Genet 1998;19:219-20.

29 Ahuja N, Mohan AL, Li Q, Stolker JM, Herman JG, Hamilton SR, Baylin SB, Issa JP. Association between CpG island methylation and microsatellite instability in colorectal cancer. Cancer Res 1997;57:3370-4.

30 Homfray TF, Cottrell SE, Ilyas M, Rowan A, Talbot IC, Bodmer WF, Tomlinson IP. Defects in mismatch repair occur after APC mutations in the pathogenesis of sporadic colorectal tumours. Hum Mutat 1998;11:114-20.

31 Tomlinson IP, Novelli MR, Bodmer WF. The mutation rate Tomlinson IP, Novelli MR, Bodmer WF. The mutation
and cancer. Proc Natl Acad Sci USA 1996;93:14800-3.

32 Young J, Leggett B, Gustafson C, Ward M, Searle J, Thomas L, Buttenshaw R, Chenevix-Trench G. Genomic instability 
occurs in colorectal carcinomas but not in adenomas. Hum Mutat 1993;2:351-4.

33 Aaltonen LA Salovaara R, Kristo P, Canzian F, Hemminki A, Peltomaki P, Chadwick RB, Kaariainen H, Eskelinen $M$, Jarvinen $\mathrm{H}$, Mecklin JP, de la Chapelle A. Incidence of hereditary nonpolyposis colorectal cancer and the feasibility of molecular screening for the disease. $N$ Engl f Med 1998;338:1481-7.

34 Thibodeau SN, French AJ, Cunningham JM, Tester D, Burgart LJ, Roche PC, McDonnell SK, Schaid DJ, Vockley
CW, Michels VV, Farr GH Jr, O’Connell MJ. Microsatellite instability in colorectal cancer: different mutator phenoypes and the principal involvement of hMLH1. Cancer Res 1998;58:1713-18.

35 Lane DP. p53 and human cancers. Br Med Bull 1994;50: 582-9.

36 Zhang H, Richards B, Wilson T, Lloyd M, Cranston A, Thorburn A, Fishel R, Meuth M. Apoptosis induced by overexpression of hMSH2 or hMLH1. Cancer Res 1999;59: 3021-7 